Nova Southeastern University

Florida

NOVA SOUTHEASTERN

UNIVERSITY

NSUWorks

Marine \& Environmental Sciences Faculty Articles Department of Marine and Environmental Sciences

6-1-1997

\title{
Observation of Large Diurnal Warming Events in the Near-Surface Layer of the Western Equatorial Pacific Warm Pool
}

\author{
Alexander Soloviev \\ Nova Southeastern University, soloviev@nova.edu \\ Roger Lukas \\ University of Hawaii - Manoa \\ Find out more information about Nova Southeastern University and the Halmos College of Natural Sciences \\ and Oceanography.
}

Follow this and additional works at: https://nsuworks.nova.edu/occ_facarticles

Part of the Marine Biology Commons, and the Oceanography and Atmospheric Sciences and Meteorology Commons

\section{NSUWorks Citation}

Alexander Soloviev and Roger Lukas. 1997. Observation of Large Diurnal Warming Events in the Near-Surface Layer of the Western Equatorial Pacific Warm Pool .Deep Sea Research Part I: Oceanographic Research Papers , (6) : 1055 -1076.

https://nsuworks.nova.edu/occ_facarticles/649.

This Article is brought to you for free and open access by the Department of Marine and Environmental Sciences at NSUWorks. It has been accepted for inclusion in Marine \& Environmental Sciences Faculty Articles by an authorized administrator of NSUWorks. For more information, please contact nsuworks@nova.edu. 


\title{
Observation of large diurnal warming events in the near-surface layer of the western equatorial Pacific warm pool
}

\author{
ALEXANDER SOLOVIEV*† and ROGER LUKAS*
}

(Received 5 September 1995; accepted 4 June 1996)

\begin{abstract}
Because of the relatively calm winds which prevail over the western Pacific warm pool, the diurnal cycle of temperature in the near-surface layer of the ocean is often quite pronounced. During the TOGA Coupled Ocean-Atmosphere Response Experiment (COARE), very high resolution measurements of near-surface thermohaline and turbulence structures were made using bowmounted probes and a free-rising profiler. Experimental data demonstrate a strong dependence of near-surface thermal structure on weather conditions. In calm weather, SST was observed to exceed $33.25^{\circ} \mathrm{C}$; this was associated with a diurnal warming of more than $3^{\circ} \mathrm{C}$ in the top $1 \mathrm{~m}$ of the ocean. A 1-D model of transilient type reproduces the diurnal cycle at low wind speeds and the evening deepening of the diurnal thermocline. Precipitation influenced the diurnal cycle by trapping heat in the near-surface region. During daytime evaporation, surface salinity increased slightly, but deep convection was inhibited by the strong vertical temperature gradient. Contour plots calculated using observations from bow sensors "scanning" the upper meters of the ocean due to ship's pitching in some cases revealed strong horizontal variability of the shallow diurnal thermocline with amplitude $\sim 2^{\circ} \mathrm{C}$ on scales of $0.2-6 \mathrm{~km}$. (C) 1997 Elsevier Science Ltd
\end{abstract}

\section{INTRODUCTION}

The coupled ocean-atmosphere system in the western equatorial Pacific warm pool is very sensitive even to small changes of boundary conditions (Lukas and Lindstrom, 1991; Webster and Lukas, 1992). Diurnal variations of SST may result in strong interaction with the overlying atmosphere through enhanced convection, which acts as a negative feedback by increasing cloudiness (Chen et al., 1996; Webster et al., 1996), and by increased evaporative and sensible heat loss from cold downdrafts (Greenhut, 1978; Gautier, 1978; Lukas, 1990a). The relative diurnal temperature changes both in the ocean and in the atmosphere are of importance (Kraus and Businger, 1994).

At low wind speeds, the diurnal thermocline is localized in the upper meters of the ocean (Bruce and Firing, 1974; Soloviev and Vershinsky, 1982); the amplitude of the diurnal cycle sometimes achieves several ${ }^{\circ} \mathrm{C}$ (Stramma et al., 1986; Flament et al., 1994). Positive buoyancy flux due to diurnal heating may strongly suppress turbulent exchange in the nearsurface layer of the ocean. The heated near-surface layer is then slipping over the underlying water practically without friction (Kudryavtsev and Soloviev, 1990). The kinetic energy of the slipping near-surface layer accumulated during the daytime is then released during the evening deepening of the diurnal thermocline, increasing the turbulent

\footnotetext{
* Department of Oceanography, University of Hawaii, 1000 Pope Road, Honolulu, HI 96822, U.S.A.

$\dagger$ Permanent affiliation is at the Nova Southeastern University's Oceanography Center, Dania, FL 33004, U.S.A.
} 
mixing. Background salinity stratification formed by a previous rain event may substantially modify the diurnal cycle, trapping diurnal heating near the surface (Anderson et al., 1996).

Observations performed in the western Pacific warm pool during the Western Equatorial Pacific Ocean Circulation Study (WEPOCS) indicated that because of the relatively calm winds that occur over the western Pacific warm pool, the amplitude of the diurnal cycle of temperature in the near-surface layer of the ocean was sometimes quite pronounced (Taft and McPhaden, 1990; Lukas, 1991). The aim of this paper is to present new field data on large diurnal warming events in the western Pacific warm pool. Section 2 contains a short description of the study of the diurnal cycle in the western Pacific warm pool during WEPOCS. Section 3 briefly describes new instrumentation and techniques used for the study of the near-surface layer of the ocean during TOGA COARE. In Section 4 we describe vertical and horizontal structure of the diurnal warming of the near-surface layer of the ocean observed in the TOGA COARE domain. Section 5 contains discussion and conclusions.

\section{STUDY DURING WEPOCS}

A preliminary study of the diurnal cycle in the western Pacific warm pool was performed by one of the authors of this paper in the frameworks of WEPOCS. Hourly observations of near-surface temperature range were made during WEPOCS cruise III on R.V. Moana Wave from 16 June to 31 July 1988 (Lukas, 1991) using bucket thermometers sampling at approximately $0.5 \mathrm{~m}$ (this, of course, underestimates the diurnal range of SST in calm weather). Wind, wet and dry air temperature, and cloud amount (oktas) were also measured every hour. Complete observations were available for 36 days.

For each day, the range of SST $\left(\Delta T_{\max }\right)$ was computed, along with the daily mean wind speed and the daytime mean cloud amount. The daily minimum SST ranged from $28^{\circ} \mathrm{C}$ to $29.5^{\circ} \mathrm{C}$, and the daily maximum ranged from $29.3^{\circ} \mathrm{C}$ to $31.1^{\circ} \mathrm{C}$, while $\Delta T_{\max }$ varied from $0.25^{\circ} \mathrm{C}$ to almost $2^{\circ} \mathrm{C}$. Daily mean wind speed was as light as $1 \mathrm{~m} \mathrm{~s}^{-1}$, with a maximum of almost $11 \mathrm{~m} \mathrm{~s}^{-1}$. Daylight average cloud cover ranged from about $1 / 4$ to complete coverage.

Figure $\mathrm{lb}$ demonstrates daily observations of the range of near-surface warming during WEPOCS. On some days, the amplitude of the diurnal warming exceeded $2^{\circ} \mathrm{C}$. There is an apparent but noisy dependence of SST range on both wind speed and cloud amount, with increased wind and cloud being associated with reduced diurnal SST range. Figure la shows the simple regression suggested by Lukas (1991):

$$
\Delta T_{\max }=0.75+14.67 \frac{\left(1-C_{\mathrm{f}}\right)}{U^{2}},
$$

to connect SST range $\left(\Delta T_{\max }\right)$, daily average cloud fraction $\left(C_{\mathrm{f}}\right)$, and daily average wind speed $(U)$. The presence of $U^{-2}$ on the right side of the regression implies that below some critical value of the wind speed the diurnal warming increases dramatically. Equation (1) is derived using the data only at $U>2.7 \mathrm{~m} \mathrm{~s}^{-1}$, because the scatter of points strongly increases at very low wind speed. This equation should not therefore be applied for very low and calm winds. 


\section{WEPOCS III (16 June - 31 July 1988)}
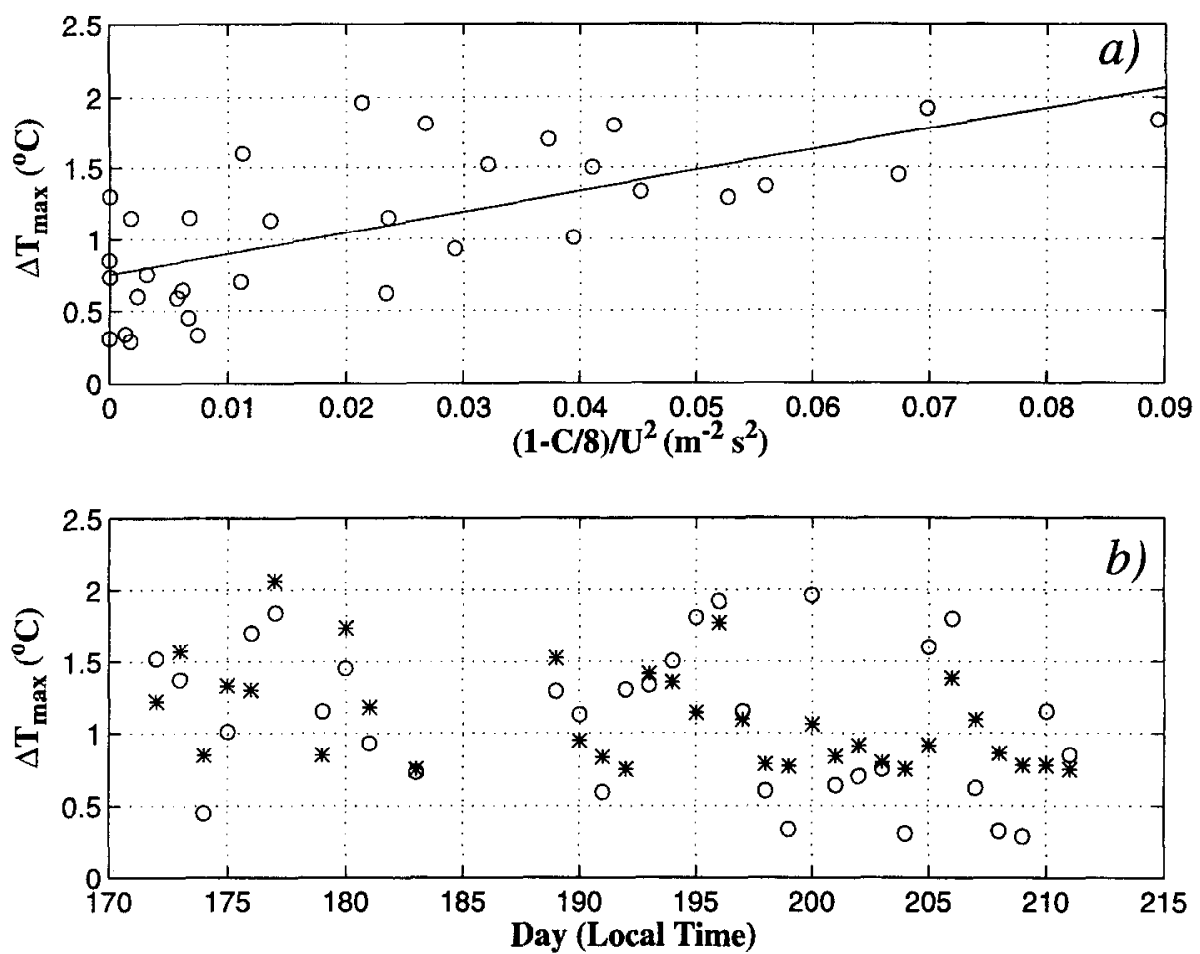

Fig. 1. (a) Diurnal SST range $\left(\Delta T_{\max }\right)$ versus combined cloud $(C)$ and wind speed $(U)$ parameter. Open circles are the filed data. The results of the regression are plotted as a straight line. (b) SST range: observed (open circles) and predicted (asterisk) by parameterization (1). Details are in Lukas (1991).

\section{MEASUREMENTS DURING TOGA COARE}

During TOGA COARE, we used instrumentation and techniques specially developed for near-surface measurements. Figure 2 schematically shows deployment of the devices from the R.V. Moana Wave. A photo of the free-rising profiler and the bow sensors is shown in Fig. 3. They are described briefly below. Details are in Soloviev et al. (1995). Data from the dropsonde are not used in this paper.

\subsection{Free-rising proflier}

The measurements with the free-rising profiler (Fig. 3d) were made from the drifting ship. The profiler, connected with the "shuttle" (winged frame), was deployed from the stern of Moana Wave with the help of a metal construction that provided initial sliding of the device from the ship to water (Fig. 3c). After leaving the metal frame the profiler fell into the water and slid outside the ship's wake by a distance of about 15-35 m as it sank (Fig. 2). This distance depended on the drift of the ship and the intensity of near-surface currents. Normally at $18 \mathrm{~m}$ depth the pressure release mechanism released the profiler from the 
"shuttle" and it turned to a vertical orientation. The profiler then rose to the surface from the depth of detachment of the "shuttle" with a vertical velocity of $2-3 \mathrm{~m} \mathrm{~s}^{-1}$, which depended on the net buoyancy of the profiler. The profiler had a rather large net buoyancyto-weight ratio that provided nearly constant vertical speed with respect to the surrounding water (see details in Soloviev et al., 1988). The technical characteristics of the free-rising profiler probes for the data being analyzed in this paper are given in Table 1.

\subsection{Bow probes}

Bow probes included the electrical conductivity, temperature and pressure (ECTP) probe and the electromagnetic velocity and acceleration (EMVA) probes (Fig. 3a). A special metal frame was designed to install probes on the bow of the vessel (see Figs 2 and $3 b$ ). To reduce the influence of the dynamical component, the pressure sensor was placed in a tail part of the bow probe. Uncertainty in depth reading at full speed of the ship was $\sim 0.1 \mathrm{~m}$ (Soloviev and Lukas, 1996). At ship speed $>2 \mathrm{~m} \mathrm{~s}^{-1}$ the probes gave information from an undisturbed flow ahead of the moving vessel. The EMVA data are not used in this paper. Table 2 gives the main technical characteristics of the ECTP probes in COARE cruises MW4310 and MW4311 (EQ-3) of the R.V. Maana Wave.

\subsection{Pertinent information}

During cruise EQ-3 the R.V. Moana Wave was equipped with a standard thermosalinograph system pumping seawater from $3 \mathrm{~m}$ depth in a bow area. Wind speed was measured continuously at a $15 \mathrm{~m}$ height. We used $5 \mathrm{~min}$ averaged wind speed. Standard meteorological observations every $6 \mathrm{~h}$ included dry and wet air temperature, bucket thermometer water temperature, clouds, etc. Solar insolation ( $20 \mathrm{~min}$ averages) was measured from 2 to 10 May 1994. During the measurements by FRP on 4 May 1994 the meteorological observations were performed every $\sim 15 \mathrm{~min}$. Table 3 contains pertinent information on all the examples being analyzed in this paper.

\section{STRUCTURE OF DIURNAL MIXED LAYER AND DIURNAL THERMOCLINE}

\subsection{Turbulent mixing at low wind speed}

At low wind speeds, the turbulent mixing in the near-surface layer of the ocean is driven mainly by wind-induced shear and convection due to densification on account of evaporation and possible net surface cooling. During the daytime, absorption of solar radiation produccs a positive buoyancy flux restricting the depth of penetration of turbulence generated near the air-sea interface. A so-called diurnal mixed layer (DML) and diurnal thermocline (DT) are formed. Figure 4 illustrates the turbulence regime of the near-surface layer of the ocean under conditions of low wind speed and strong solar insolation. Mean temperature profile $\bar{T}$ is obtained by averaging 10 vertical profiles for the period 15:54-16:54 LST (see Fig. 5b and Table 3) on appropriate depths that are sampled every $0.7 \mathrm{~cm} \mathrm{(} 400 \mathrm{~Hz}$ sampling rate). The vertical profile of standard deviation of the strain fluctuation, $\left\langle\operatorname{std}\left(\mathrm{d} u^{\prime} / \mathrm{d} z\right)\right\rangle$, is calculated for each depth interval on the corresponding 10 vertical profiles of $u^{\prime}$ (here $u^{\prime}$ is the fluctuation of the longitudinal velocity and $z$ is the depth). 


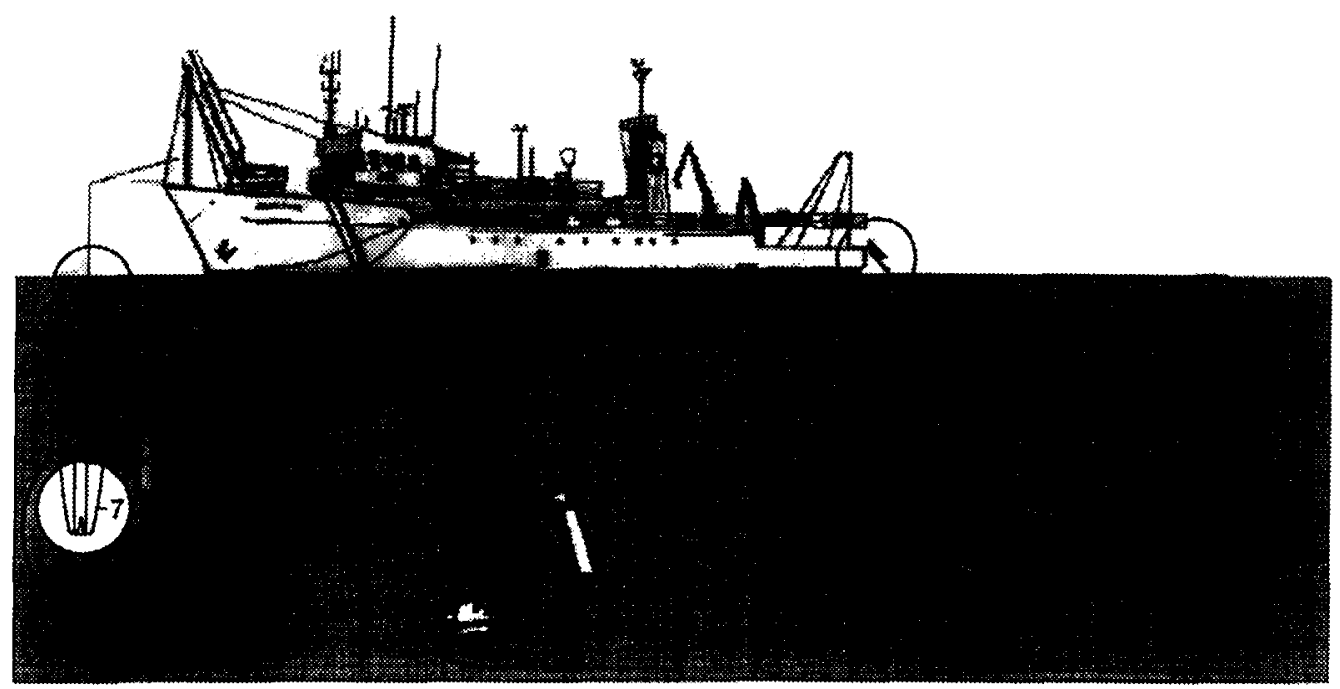

Fig. 2. Schematic illustration of devices deployed for small-scale measurements near the ocean-air interface on the R.V. Mouna Wave. Here 1-free-rising profiler coupled with carrier; 2temperature, conductivity and fluctuation-velocity probes on free-rising proflier; 3-carrier; 4 bow frame; 5-bow units (temperature, conductivity, pressure sensor; fluctuation-velocity, tilt sensor); 6-dropsonde; 7-temperature probe of microwire type. 


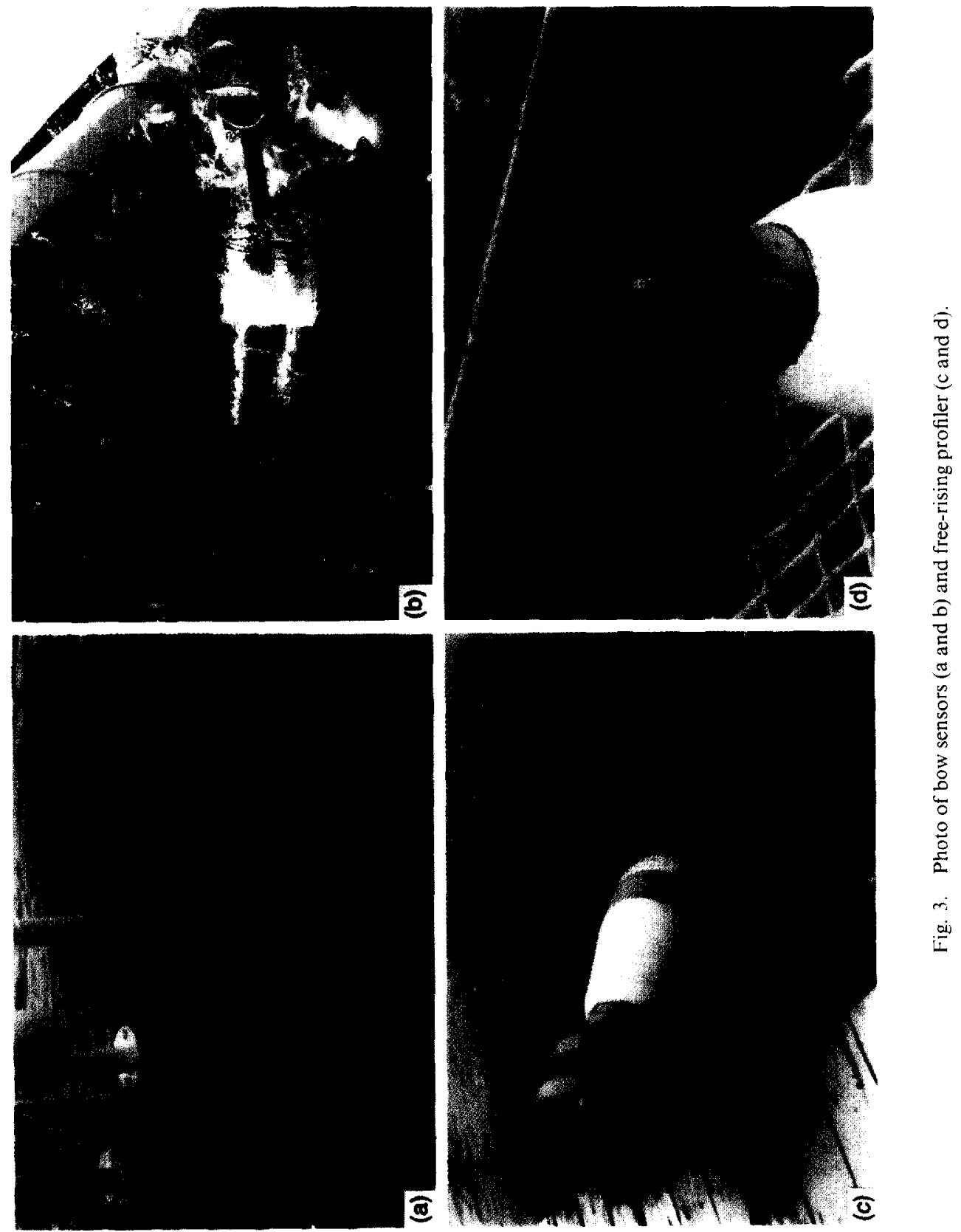




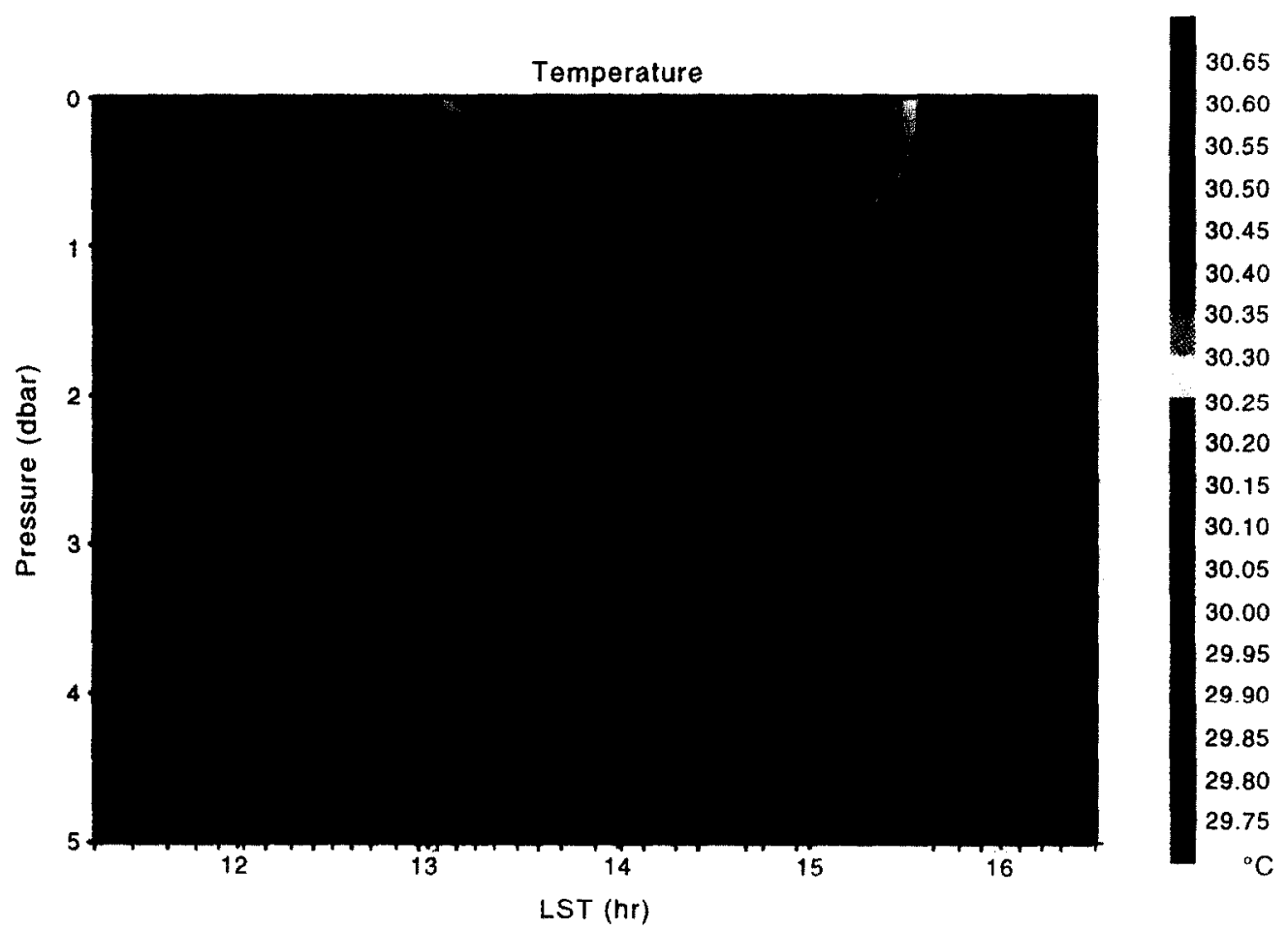

Fig. 7. Contour plot of temperature in the upper ocean at low wind speed. Measurements by freerising profiler on 4 May 1994. 


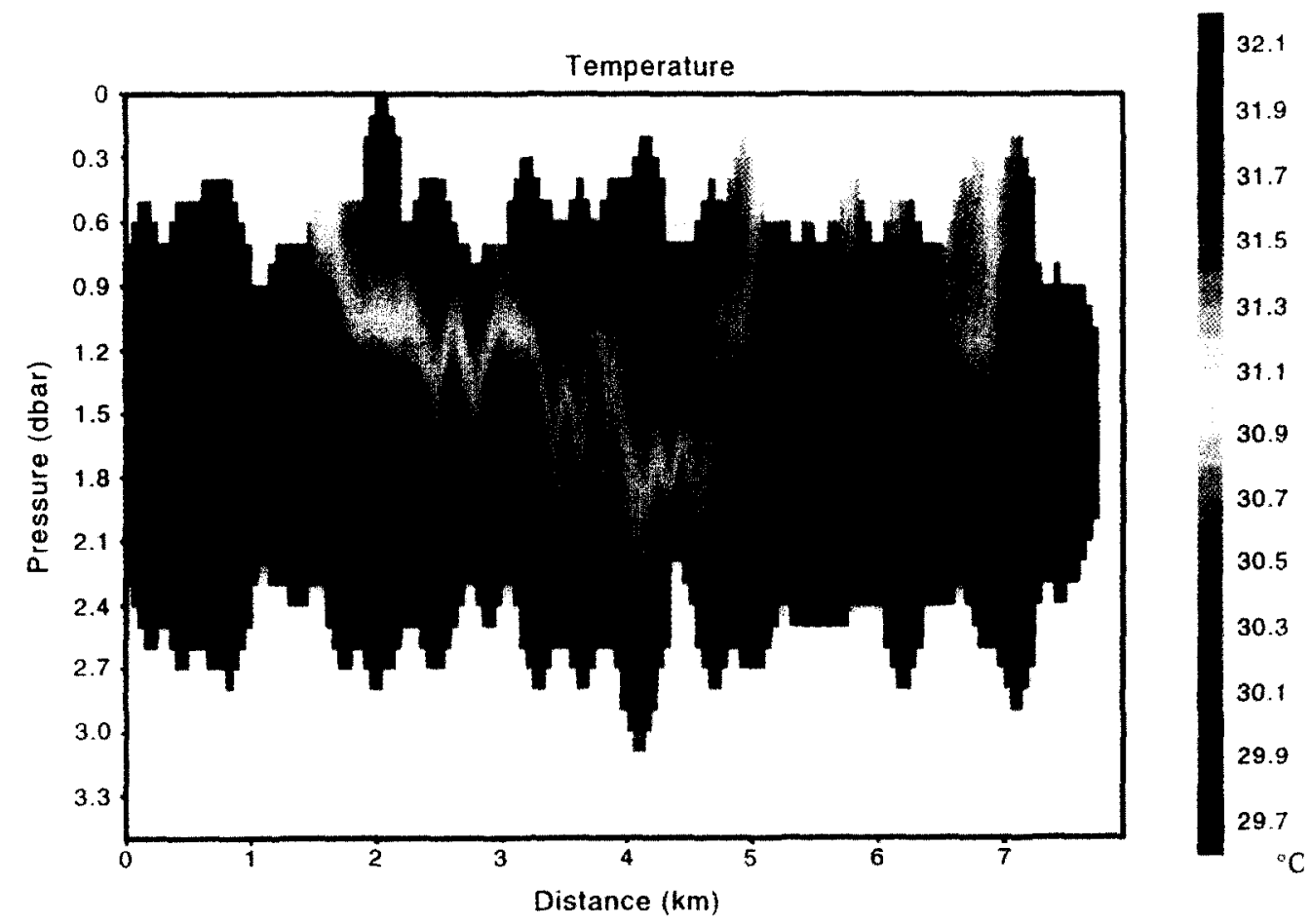

Fig. 14. Contour plot of temperature in the upper $3 \mathrm{~m}$ from measurements by bow sensors for 21 April 1994. 
Table 1. Main technical characteristics of probes of free-rising profiler in COARE transit and EQ-3 cruises of Moana Wave

\begin{tabular}{|c|c|}
\hline \multicolumn{2}{|l|}{ Temperature (regular probe) } \\
\hline Range $\left({ }^{\circ} \mathrm{C}\right)$ & $14-34$ \\
\hline Accuracy $\left({ }^{\circ} \mathrm{C}\right)$ & 0.1 \\
\hline Stability during one profiling $\left({ }^{\circ} \mathrm{C}\right)$ & $<0.01$ \\
\hline Digital resolution $\left({ }^{\circ} \mathrm{C}\right)$ & 0.005 \\
\hline Response time of sensor (ms) & 35 \\
\hline \multicolumn{2}{|l|}{ Fast temperature ("DISA" probe)* } \\
\hline Range $\left({ }^{\circ} \mathrm{C}\right)$ & $-2-35$ \\
\hline Accuracy $\left({ }^{\circ} \mathrm{C}\right)$ & 0.1 \\
\hline Stability during one profiling $\left({ }^{\circ} \mathrm{C}\right)$ & 0.01 \\
\hline Digital resolution $\left({ }^{\circ} \mathrm{C}\right)$ & 0.005 \\
\hline Response time of sensor (ms) & 3 \\
\hline \multicolumn{2}{|l|}{ Conductivity (G3 cell) } \\
\hline Range $(S / m)$ & $1.0-6.2$ \\
\hline Accuracy $(\mathrm{S} / \mathrm{m})$ & 0.01 \\
\hline Stability during one profiling $(\mathrm{S} / \mathrm{m})$ & $<0.001$ \\
\hline Digital resolution $(\mathrm{S} / \mathrm{m})$ & 0.0008 \\
\hline Spatial resolution $(\mathrm{cm})$ & 1 \\
\hline \multicolumn{2}{|l|}{ Depth (Pressure) } \\
\hline Range (m) & $0-25$ \\
\hline Accuracy (m) & $0.1^{* *}$ \\
\hline Stability during one profiling (m) & 0.01 \\
\hline Resolution (m) & 0.01 \\
\hline \multicolumn{2}{|l|}{$V x$ fluctuation velocity sensor } \\
\hline Range $\left(\mathrm{m} \mathrm{s}^{-1}\right)$ & \pm 0.25 \\
\hline Accuracy $(\%)$ & 5 \\
\hline Noise level $\left(\mathrm{mm} \mathrm{s}^{-1}\right)$ & $<1$ \\
\hline Frequency range $(\mathrm{Hz})$ & $2-150$ \\
\hline Digital resolution $\left(\mathrm{mm} \mathrm{s}^{-1}\right)$ & 0.6 \\
\hline
\end{tabular}

*Installed together with regular temperature probe only for series of measurements on 4 May 1994

${ }^{* *}$ After correction of temperature and dynamicalpressure dependence.

The brackets, $\rangle\rangle$, denote additional smoothing on depth. For this purpose, we used a zerophase low-pass filter (Oppenheim and Schafer, 1975) with cut-off wavenumber equivalent to $k_{c u t}=12.5 \mathrm{~m}^{-1}$. The mean temperature profile $\bar{T}$ shown in Fig. 4a reveals the DML of about $1 \mathrm{~m}$ depth and the DT in the depth range of 1 to $10 \mathrm{~m}$. The vertical profile of $\left\langle\operatorname{std}\left(\mathrm{d} u^{\prime} / \mathrm{d} z\right)\right\rangle$ shows that the fluctuation velocities in DML are of maximum value. They decrease by a factor of $\sim 4$ within the DT compared to the maximum value in the DML. Below DT the fluctuation velocity signal is close to the noise level of the velocity probe.

A specific feature of the turbulent mixing in the near-surface layer of the ocean under light winds is that it both influences, and is influenced by, stratification due to diurnal heating. This results in a non-linear response of the diurnal cycle to external forcing. The amplitude of diurnal warming of the near-surface layer of the ocean dramatically increases at low wind speeds, which is explained by damping of turbulent mixing by positive buoyancy flux. The next sections elucidate this effect. 
Table 2. Main technical characteristics of ECTP probe in COARE Transit and EQ-3 cruises of the $R . V$. Moana Wave

\begin{tabular}{lc} 
Temperature & \\
Range $\left({ }^{\circ} \mathrm{C}\right)$ & $14-34$ \\
Accuracy $\left({ }^{\circ} \mathrm{C}\right)$ & $<0.1$ \\
Stability during $8 \mathrm{~h}\left({ }^{\circ} \mathrm{C}\right)$ & $<0.01$ \\
Digital resolution $\left({ }^{\circ} \mathrm{C}\right)$ & 0.005 \\
Response time of primary sensor $(\mathrm{ms})$ & 35 \\
Conductivity & \\
Range $(\mathrm{S} / \mathrm{m})$ & $3.1-6.1$ \\
Accuracy $(\mathrm{S} / \mathrm{m})$ & $<0.01$ \\
Stability during $8 \mathrm{~h}(\mathrm{~S} / \mathrm{m})$ & $<0.001$ \\
Digital resolution $(\mathrm{S} / \mathrm{m})$ & 0.0012 \\
Space resolution $(\mathrm{m})$ & 0.1 \\
Pressure & \\
Range $($ dbar $)$ & $0-25$ \\
Accuracy $(\mathrm{dbar})$ & $0.1^{*}$ \\
Digital resolution $(\mathrm{dbar})$ & 0.01 \\
\hline
\end{tabular}

*After correction of temperature dependence.

\subsection{Wind-speed dependence}

The field data presented below serve to demonstrate the strong dependence of the diurnal heating on the wind speed. Figure $5(\mathrm{a}, \mathrm{b}$ and $\mathrm{c})$ contains an example of three series of vertical temperature profiles obtained during the afternoon at different wind speeds.

The series of nine profiles shown in Fig. 5a was obtained at moderate wind-speed $\left(7 \mathrm{~m} \mathrm{~s}^{-1}\right.$ wind speed) and clouds of medium height (cloud fraction 6/8). The depth of the diurnal mixed layer was from 12 to $17 \mathrm{~m}$, and the maximum temperature difference in the upper $18 \mathrm{~m}$ was about $0.2^{\circ} \mathrm{C}$.

The series of 10 temperature profiles shown in Fig. 5b was obtained at low wind speed $\left(\sim 2 \mathrm{~m} \mathrm{~s}^{-1}\right)$ and clouds of medium height (cloud fraction 2/8), demonstrating more substantial diurnal heating of the near-surface layer. The depth of the diurnal mixed layer was about 1 to $7 \mathrm{~m}$, and the temperature difference across the diurnal thermocline was about $0.6-0.8^{\circ} \mathrm{C}$. An interesting feature of this series of profiles is a diurnal thermocline of almost constant thickness but of variable depth, changing from one cast to another.

The series of five temperature profiles obtained in calm weather and large height clouds (cloud fraction 2/8) shows that the diurnal heating is localized mainly in the upper $1 \mathrm{~m}$ layer of the ocean (Fig. 5c). The temperature difference across the diurnal thermocline is larger than $3^{\circ} \mathrm{C}$, the sea surface temperature reaching $33.25^{\circ} \mathrm{C}$.

Simple scale analysis (Kudryavtsev and Soloviev, 1990) shows that the dramatically increasing amplitude of the diurnal heating at low wind speed is associated with a strong decrease of the DML-depth at decreasing wind speed. This is consistent with regression (1) obtained by Lukas (1991) showing " -2 " power dependence of the diurnal warming amplitude on the wind speed.

The solar insolation is another important parameter. Based on the cloud information, we can conclude that for the example shown in Fig. $5 \mathrm{c}$ the short-wave solar radiation forcing was larger than for examples $a$ and $b$ shown in the same figure. The heat and momentum flux 
Table 3. Conditions of measurements during the TOGA COARE presented in this paper

\begin{tabular}{|c|c|c|c|c|c|c|c|}
\hline Figure & $\begin{array}{c}\text { Date GMT } \\
(1994)\end{array}$ & Time (GMT) & Time (LST) & Latitude & Longitude & $\begin{array}{l}\text { Wind speed } \\
\left(\mathrm{m} \mathrm{s}^{-1}\right)\end{array}$ & Comments \\
\hline $4,5 b$ & $26 \mathrm{Apr}$ & $5: 25-6: 25$ & $15: 54-16: 54$ & $06^{\circ} 12^{\prime} \mathrm{N}$ & $157^{\circ} 14^{\prime} \mathrm{E}$ & $2.1-5.0$ & 10 profiles \\
\hline $5 \mathrm{a}$ & $16 \mathrm{Apr}$ & $03: 48-04: 50$ & $14: 48-15: 50$ & $00^{\circ} 31^{\prime} S$ & $165^{\circ} 00^{\prime} \mathrm{E}$ & $6.8-8.2$ & 9 profiles \\
\hline $5 c$ & 1 May & $02: 59-03: 39$ & $13: 17-13: 57$ & $00^{\circ} 21^{\prime} \mathrm{S}$ & $154^{\circ} 23^{\prime} \mathrm{E}$ & 0.2 & 5 profiles \\
\hline $6,7,9,10$ & 4 May & $01: 15-06: 30$ & $10.55-16: 10$ & $00^{\circ} 02^{\prime} \mathrm{S}$ & $145^{\circ} 04^{\prime} \mathrm{E}$ & $0.3-4.2$ & 35 profiles \\
\hline \multirow[t]{7}{*}{8} & 2 May- & $23: 04-23: 13$ & $09: 00-09: 10$ & $00^{\circ} 00^{\prime} \mathrm{N}$ & $149^{\circ} 02^{\prime} \mathrm{E}$ & $2.7-2.9$ & $10 \mathrm{~min}$ \\
\hline & 3 May & $01: 04-01: 13$ & $10: 59-11: 08$ & $00^{\circ} 01^{\prime} \mathrm{N}$ & $148^{\circ} 43^{\prime} \mathrm{E}$ & $1.0-1.4$ & averages \\
\hline & & $03: 04-03: 13$ & $12: 58-13: 07$ & $00^{\circ} 01^{\prime} \mathrm{N}$ & $148^{\circ} 24^{\prime} \mathrm{E}$ & $0.4-0.6$ & \\
\hline & & $05: 04-05: 13$ & $14: 56-15: 05$ & $00^{\circ} 01^{\prime} \mathrm{N}$ & $148^{\circ} 05^{\prime} \mathrm{E}$ & $2.2-2.4$ & \\
\hline & & $07: 04-07: 13$ & $16: 56-17: 05$ & $00^{\circ} 00^{\prime} \mathrm{N}$ & $148^{\circ} 00^{\prime} \mathrm{E}$ & $2.7-4.6$ & \\
\hline & & $09: 04-09: 13$ & $18: 55-19: 04$ & $00^{\circ} 06^{\prime} \mathrm{N}$ & $147^{\circ} 49^{\prime} \mathrm{E}$ & $1.7-4.3$ & \\
\hline & & $11: 04-11: 13$ & $20: 54-21: 03$ & $00^{\circ} 03^{\prime} \mathrm{N}$ & $147^{\circ} 31^{\prime} \mathrm{E}$ & $4.0-4.9$ & \\
\hline 11 & $2 \mathrm{Apr}$ & $06: 22-07: 52$ & $16: 46-18: 16$ & $00^{\circ} 45^{\prime} \mathrm{S}$ & $156^{\circ} 01^{\prime} \mathrm{E}$ & 3.0 & 8 profiles \\
\hline 12 & $26 \mathrm{Apr}$ & $04: 48-04: 52$ & $15: 17-15: 21$ & $06^{\circ} 14^{\prime} \mathrm{N}$ & $157^{\circ} 18^{\prime} \mathbf{E}$ & $2.8-5.0$ & Cont. plot \\
\hline 12 & $1 \mathrm{May}$ & $05: 03-05: 12$ & $15: 20-15: 29$ & $00^{\circ} 12^{\prime} \mathrm{S}$ & $154^{\circ} 11^{\prime} \mathrm{E}$ & $0.9-1.1$ & Cont. plot \\
\hline \multirow[t]{7}{*}{13} & $25 \mathrm{Apr}-$ & $22: 24-22: 33$ & $08: 57-09: 06$ & $07^{\circ} 00^{\prime} \mathrm{N}$ & $158^{\circ} 10^{\prime} \mathrm{E}$ & $3.5-4.4$ & $10 \mathrm{~min}$ \\
\hline & $26 \mathrm{Apr}$ & $00: 57-01: 06$ & $11: 28-11: 37$ & $06^{\circ} 44^{\prime} \mathrm{N}$ & $157^{\circ} 49^{\prime} \mathrm{E}$ & $3.6-3.9$ & averages \\
\hline & & $02: 57-03: 06$ & $13: 27-13: 36$ & $06^{\circ} 29^{\prime} \mathrm{N}$ & $157^{\circ} 33^{\prime} \mathrm{E}$ & $4.2-4.7$ & \\
\hline & & $04: 57-05: 06$ & $15: 27-15: 36$ & $06^{\circ} 13^{\prime} \mathrm{N}$ & $157^{\circ} 16^{\prime} \mathrm{E}$ & $3.5-4.9$ & \\
\hline & & $06: 49-06: 58$ & $17: 18-17: 27$ & $06^{\circ} 10^{\prime} \mathrm{N}$ & $157^{\circ} 12^{\prime} \mathrm{E}$ & $5.3-5.4$ & \\
\hline & & $08: 49-08: 58$ & $19: 17-19: 36$ & $05^{\circ} 53^{\prime} \mathrm{N}$ & $156^{\circ} 57^{\prime} \mathrm{E}$ & $4.8-5.4$ & \\
\hline & & $10: 49-10: 58$ & $21: 16-21: 25$ & $05^{\circ} 37^{\prime} \mathrm{N}$ & $156^{\circ} 41^{\prime} \mathrm{E}$ & $5.2-8.1$ & \\
\hline \multirow[t]{7}{*}{13} & $30 \mathrm{Apr}-$ & $23: 01-23: 10$ & $09: 20-09: 29$ & $00^{\circ} 48^{\prime} \mathrm{S}$ & $154^{\circ} 45^{\prime} \mathrm{E}$ & $1.7-1.9$ & $10 \mathrm{~min}$ \\
\hline & 1 May & $01: 21-01: 30$ & $11: 39-11: 48$ & $00^{\circ} 29^{\prime} \mathrm{S}$ & $154^{\circ} 27^{\prime} \mathrm{E}$ & $0.5-0.6$ & averages \\
\hline & & $02: 31-02: 40$ & $12: 48-12: 57$ & $00^{\circ} 22^{\prime} \mathrm{S}$ & $154^{\circ} 21^{\prime} \mathrm{F}$ & $0.4-1.0$ & \\
\hline & & $05: 01-05: 10$ & $15: 18-15: 27$ & $00^{\circ} 12^{\prime} \mathrm{S}$ & $154^{\circ} 11^{\prime} \mathrm{E}$ & $0.9-1.5$ & \\
\hline & & $06: 31-06: 40$ & $16: 47-16: 56$ & $00^{\circ} 03^{\prime} \mathrm{S}$ & $154^{\circ} 00^{\prime} \mathrm{E}$ & $1.1-1.7$ & \\
\hline & & $09: 11-09: 20$ & $19: 27-19: 36$ & $00^{\circ} 0 \mathrm{I}^{\prime} \mathrm{S}$ & $153^{\circ} 57^{\prime} \mathrm{E}$ & $1.8-2.6$ & \\
\hline & & $11: 31-11: 40$ & $21: 47-21: 56$ & $00^{\circ} 00^{\prime} \mathrm{S}$ & $153^{\circ} 57^{\prime} \mathrm{E}$ & $2.4-2.6$ & \\
\hline 14 & $21 \mathrm{Apr}$ & $03: 32-05: 41$ & $16: 26-16: 35$ & $05^{\circ} 58^{\prime} \mathrm{S}$ & $163^{\circ} 43^{\prime} \mathrm{E}$ & $0.7-1.6$ & Cont. plot \\
\hline
\end{tabular}

at the air-sea interface during the previous hours is also of importance. In the next section, we analyze observations of the diurnal cycle in the near-surface layer of the ocean performed on a 5.5-h station and accompanied by detailed measurements of the meteorological and short-wave radiation conditions.

\section{Diurnal cycle at low wind speed}

Thirty-five vertical temperature profiles during the warming and cooling phases of the diurnal cycle (Fig. 6) were obtained by free-rising profiler at low wind speed. A contour plot calculated from these 35 profiles (Fig. 7) clearly demonstrates that at low wind speed the main temperature differences due to diurnal heating are in the upper $\sim 1 \mathrm{~m}$ layer of the ocean. The individual vertical temperature profiles (Fig. 6) show that the DML-depth may decrease up to $\sim 10 \mathrm{~cm}$ or even disappear completely for some time under weak winds and strong solar insolation. The part of the vertical temperature profiles nearest the surface sometimes had a slightly unstable stratification. Negative temperature gradients may arise during daytime on account of a combination of the volume absorption of solar radiation in 


\section{Apr 94, 15:54-16:54 LST}
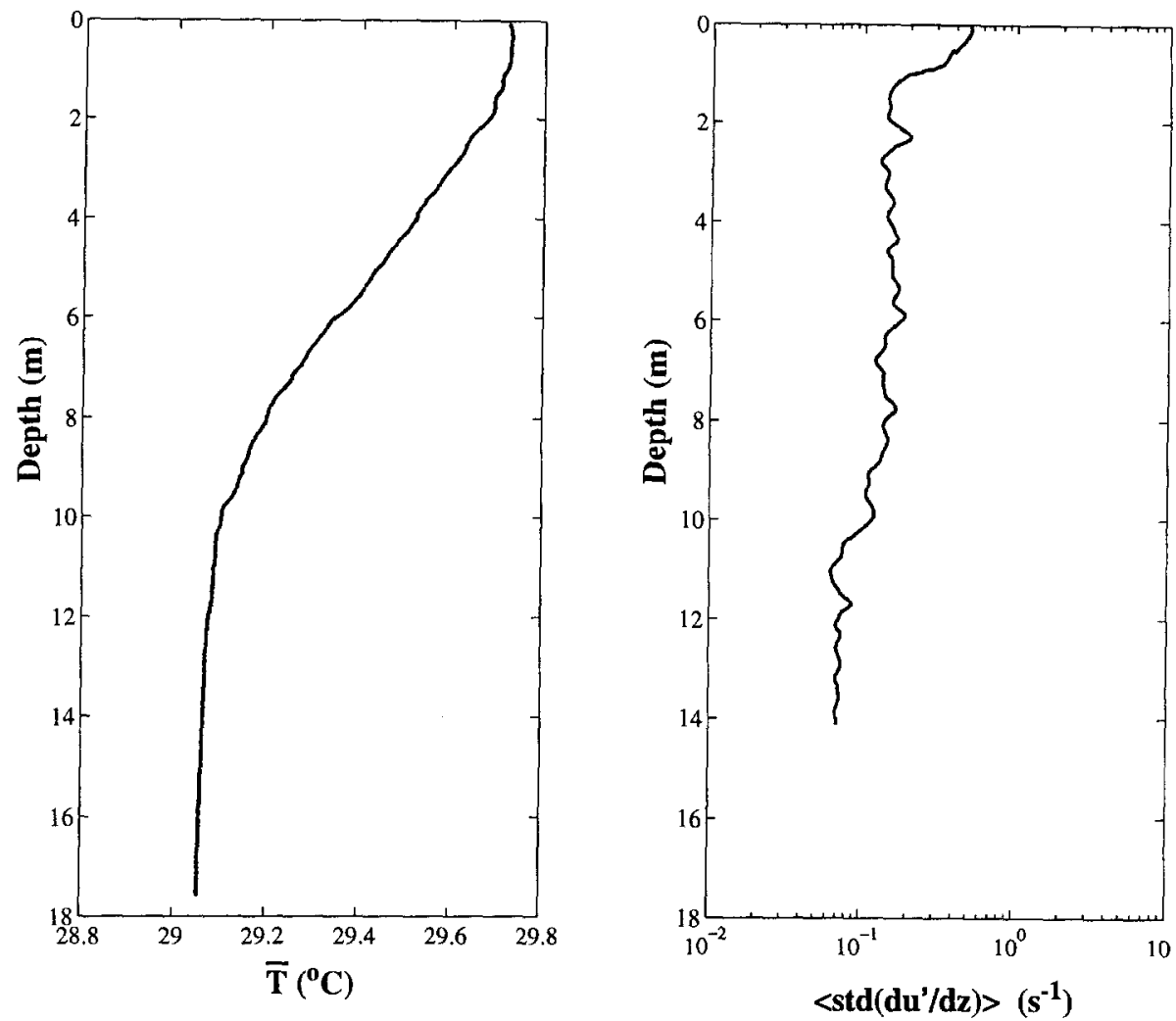

Fig. 4. Mean temperature $\overline{\mathrm{T}}$ and standard deviation of strain fluctuation std $\left(\mathrm{d} u^{\prime} / \mathrm{d} z\right)$ for the 10 frecrising profiler measurements shown in Fig. $5 \mathrm{~b}$ ( $u^{\prime}$ is the fluctuation of the longitudinal (vertical) velocity and $z$ is the depth).

the upper centimeters of the ocean and the surface cooling (Kraus and Rooth, 1961; Turner, 1973; Soloviev, 1979).

Another example of the large diurnal warming events in the western Pacific warm pool is given in Fig. 8. These are measurements by bow sensors "scanning" the near-surface layer of the ocean due to pitching of the vessel and surface waves. The depth range covered by the measurements depends on the pitching of the vessel. To increase the pitching, the vessel steamed for $\sim 15$ min every $2 \mathrm{~h}$ at $4-5$ knots perpendicular to the dominating surface-wave. These examples show the temperature difference due to diurnal heating $\sim 3^{\circ} \mathrm{C}$ and localized during noon hours in the upper $\sim 1 \mathrm{~m}$ layer of the ocean.

Figure 9 ( $a$ and b) represents heat fluxes and wind speed for measurements on 4 May 1994. Corresponding evolution of the temperature difference in the upper $8 \mathrm{~m}$ of the ocean according to FRP measurements is given in Fig. 9c by an asterisk. Dependence of the diurnal heating on the wind speed is clearly seen in this figure. During the morning wind forcing, there is practically no rise in SST. The diurnal warming is suppressed during morning hours but increases strongly at $10 \mathrm{a} \cdot \mathrm{m}$., when the wind speed drops below $5 \mathrm{~m} \mathrm{~s}^{-1}$. Calculation with a transilient model similar to that of Stull and Kraus (1987) (see details in the Appendix) properly describes the experimental data. 
Diurnal heating in the COARE domain at different wind speed conditions

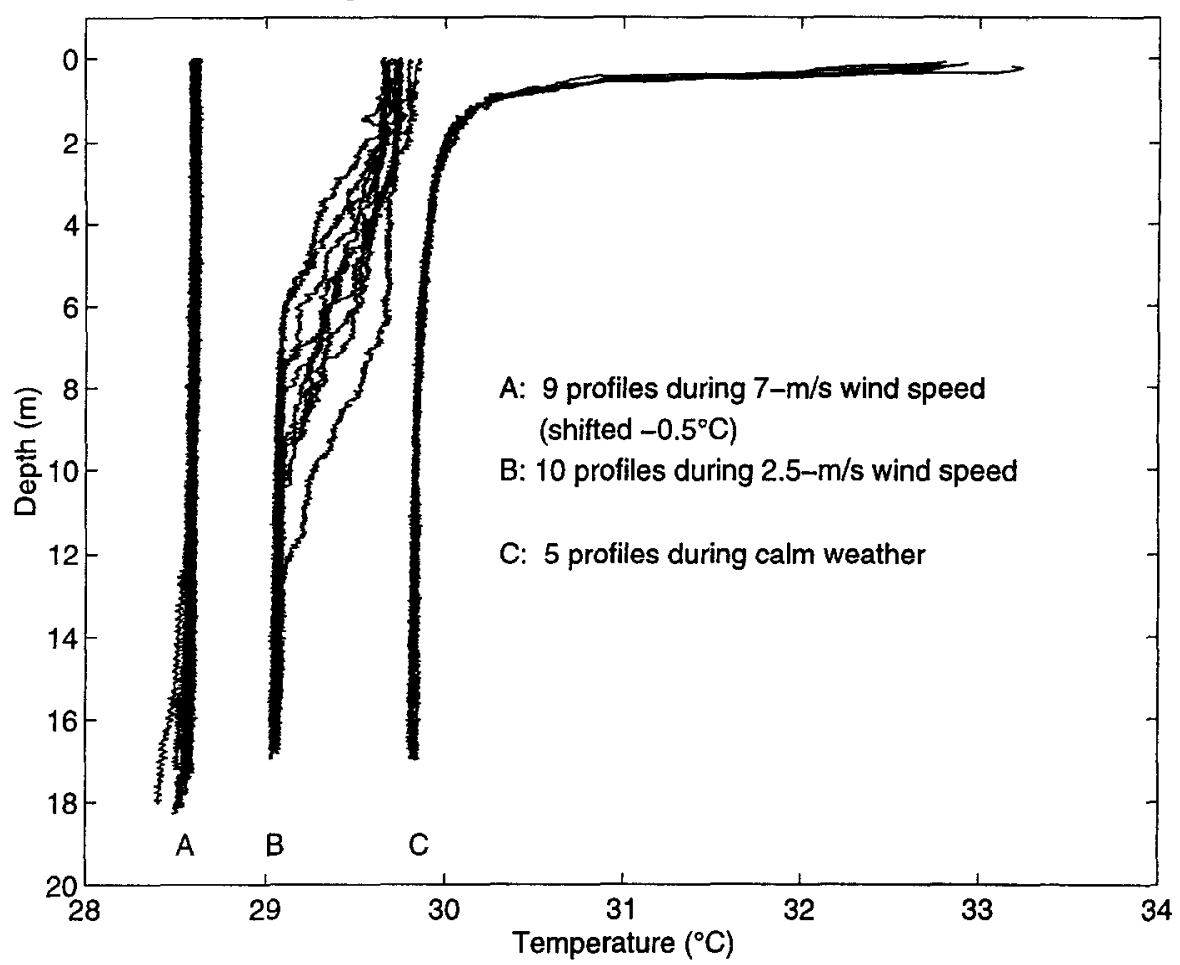

Fig. 5. Vertical temperature profiles in near-surface layer of the ocean in the TOGA COARE domain obtained by free-rising profiler at different wind speeds in the afternoon.

In Fig. 10a, the surface temperature calculated using the transilient model is compared with the bucket-thermometer and dry air temperature data. The SST calculated using the cool-skin model, including the solar radiation absorption in the upper millimeters of the ocean (Soloviev and Schluessel, 1996) is also shown. According to Fig. 10a, the daily variation in temperature in the atmosphere is even larger than it is in the ocean. Hoeber (1969) previously observed a similar effect in the equatorial region. It occurs because the moist equatorial atmosphere absorbs solar radiation directly during the daytime and is again cooled during the nighttime (see discussion in Kraus and Businger, 1994, p. 170).

Also remarkable is the diurnal variation of the relative humidity (Fig. 10b). It decreases with the diurnal SST increase, thus enhancing the latent heat flux. This is a manifestation of the negative feedback mechanism stabilizing the SST (Greenhut, 1978; Gautier, 1978; Lukas, 1990a; Kraus and Businger, 1994).

\subsection{Salinity effects}

Salinity effects may substantially modify diurnal heating of the near-surface layer in the western equatorial Pacific warm pool. Freshwater influx due to precipitation influences the diurnal cycle by trapping heat near the surface. This has been demonstrated recently by modeling of the diurnal cycle with and without rain effects and comparison with TOGA COARE mooring time series data (Anderson et al., 1996). Note the salinity depression on 3 


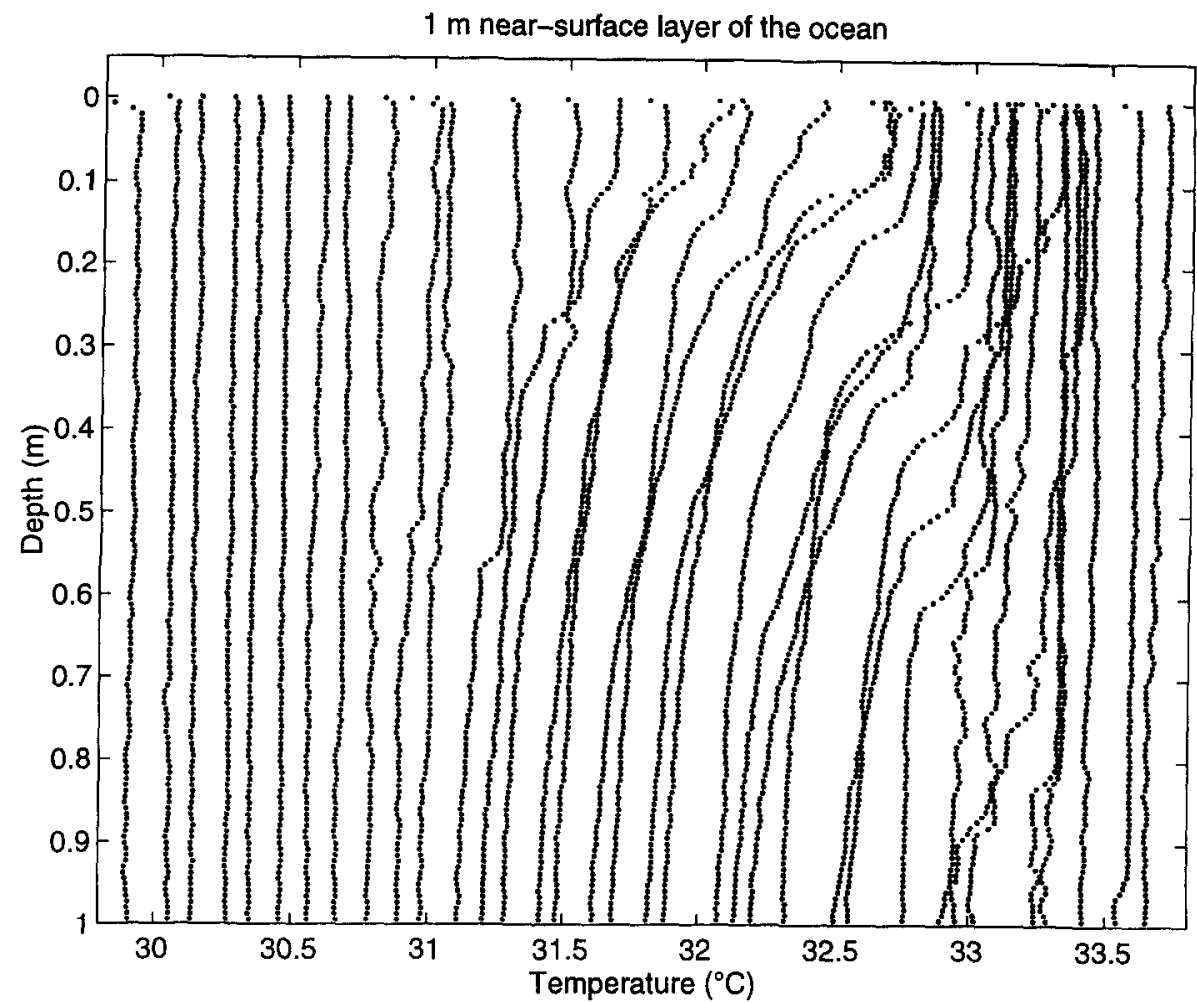

Fig. 6. Temperature profiles in the upper meter of the ocean obtained by free-rising proflier equipped with a DISA $3 \mathrm{~ms}$ response time temperature sensor (the same measurements are used in Figs 7 and 9). Each successive temperature profile is shifted by $0.1^{\circ} \mathrm{C}$. Note the cool skin effect in many of the profiles.

May at 19:00 LST (Fig. 8). This is the intersection of a rain-formed lens. The temperature difference across the diurnal thermocline here was larger than it was out of the lens because of trapping of the diurnal heating by the precipitation effects. An inversion on the density profile at $\sim 0.3 \mathrm{~m}$ is presumably concerned with lateral advection due to buoyancy adjustment within the freshwater surface lens.

Figure 11 gives experimental evidence of strong modification of vertical structure of the near-surface layer of the ocean due to rain effects in the COARE domain. It helps to understand how the combined effect of daytime solar heating and previous freshwater influx results in the strong density stratification of the upper ocean. In the case shown in Fig. 11, the diurnal thermocline develops on the background of the temperature profile of a rainformed mixed layer. According to Fig. 11 the temperature of the rain-formed mixed layer is lower than that of the underlying water mass. This is typical for a rain-mixed layer after previous night-time surface cooling (Fedorov and Ginzburg, 1988; Lukas, 1990b).

Another salinity effect is associated with usually continuous evaporation from the ocean surface even under light winds. Excess salinity is accumulated within the DML because the turbulent exchange with the underlying water mass is damped on account of stable stratification in the DT (see Fig. 4). Vertical salinity profiles in Fig. 11 show an increase of salinity of about $0.01-0.02$ within the layer of diurnal heating. The corresponding density 

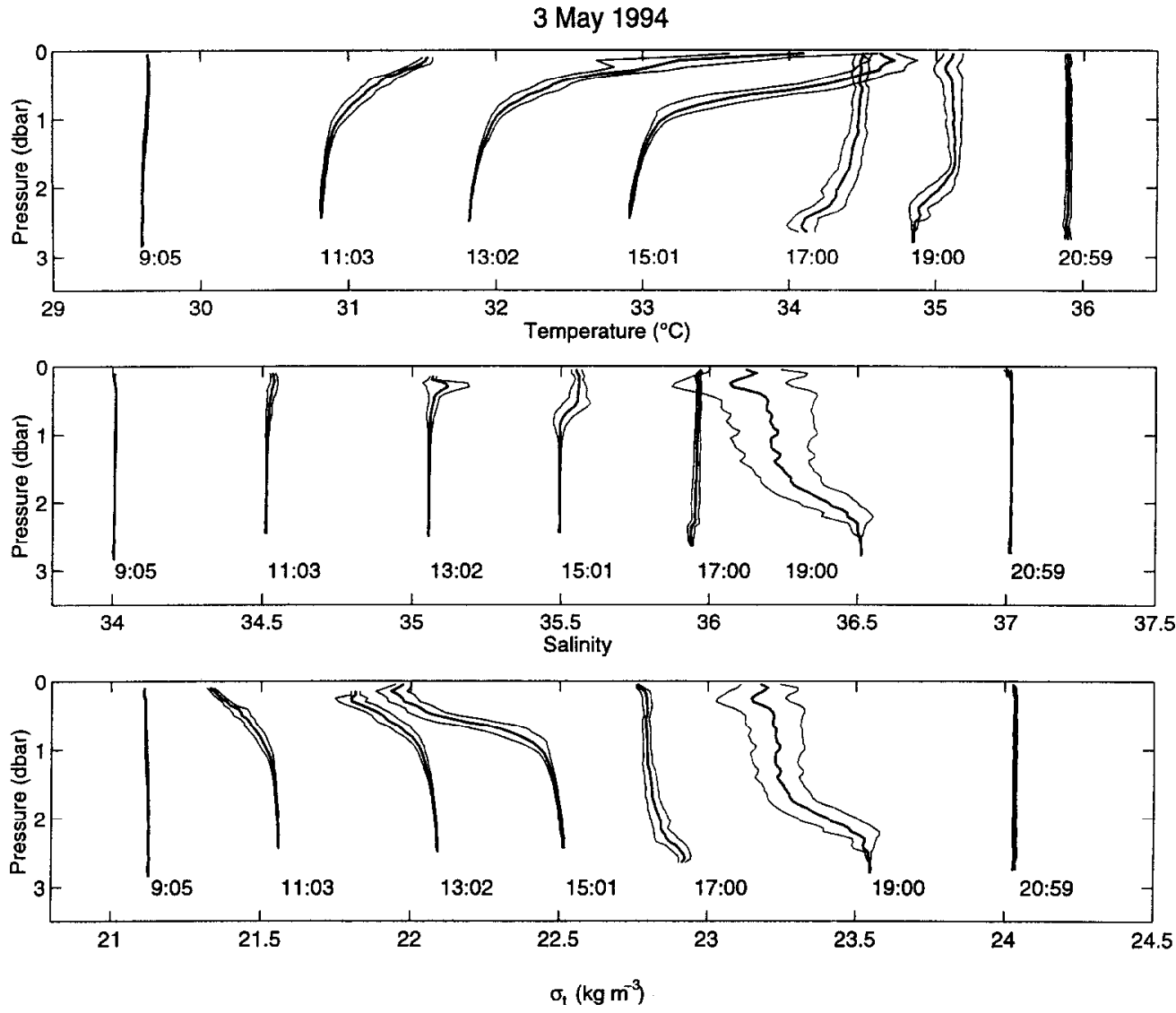

Fig. 8. Vertical profiles of temperature, salinity and density obtained by averaging the bow sensor data within 0.1 dbar pressure range on 10 min segments. Each successive temperature, salinity and density profile is shifted by $1.0^{\circ} \mathrm{C}, 0.5 \mathrm{psu}$ and $0.5 \mathrm{~kg} \mathrm{~m}^{-3}$. Under cach profile the corresponding local solar time (LST) is given. The thin lines represent \pm one standard deviation.

profiles are stable, excluding the diurnal mixed layer, where some inversions are associated with convective cooling and excess salinity. On account of effects of volume absorption of solar radiation in the upper ocean, convective cooling may exist during the daytime. Note also the slight increase of salinity within the diurnal mixed layer and diurnal thermocline on profiles in Fig. 8 (except rain event on 3 May 1994 at 19:00 LST).

In calm weather, double-diffusion effects may provide additional mixing in the stably stratified near-surface layer of the ocean. The stepped structure in the equatorial nearsurface layer after strong rain, presumably connected with layering convection, was previously reported by Soloviev and Vershinsky (1982). Conditions for salt fingers arise in the DT due to evaporation effects discussed above.

\subsection{Spatial variability}

The data obtained by the bow sensors in the near-surface layer reveal cases of strong spatial variability of the DT on scales of several hundreds of meters. A feature of the series of 

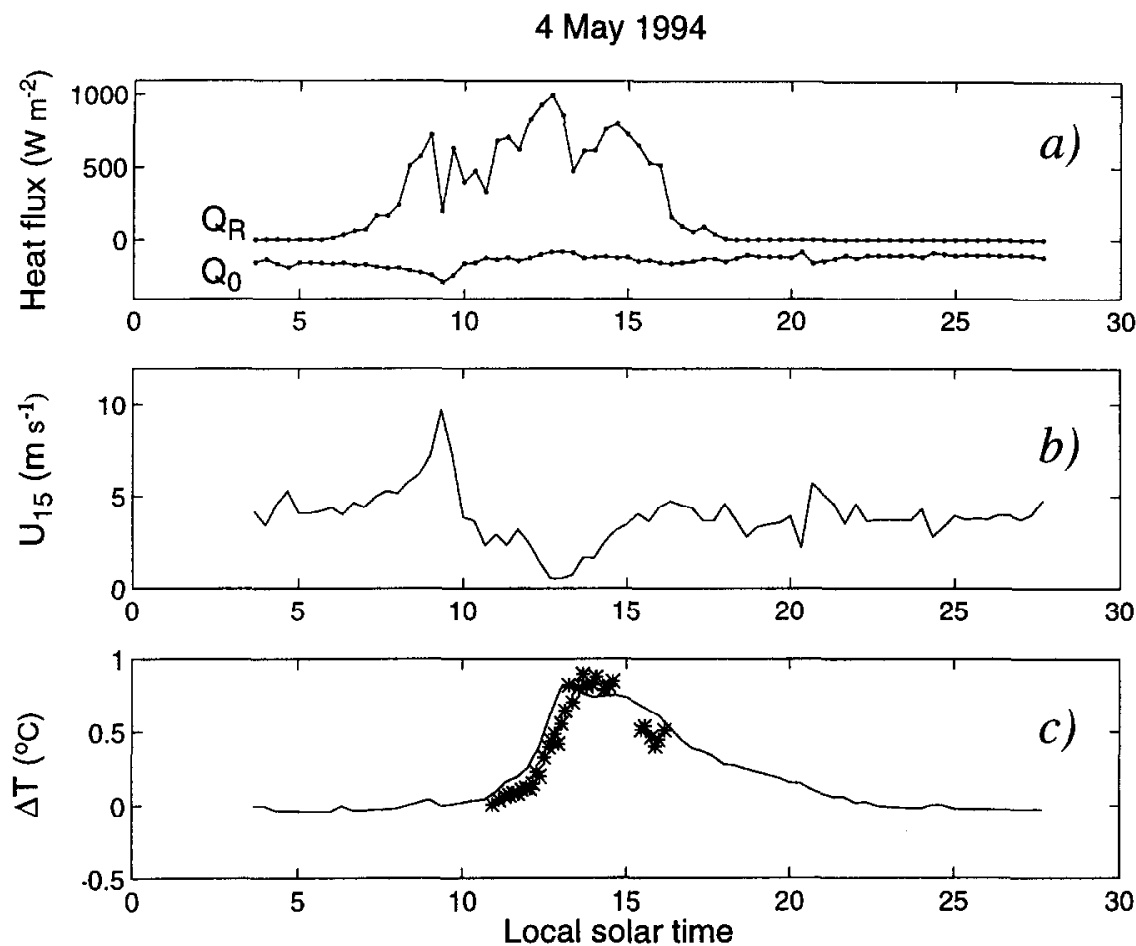

Fig. 9. Evolution of the sea surface temperature averaged within depth interval $0-0.25 \mathrm{~m}$. (a) Solar insolation $\left(Q_{R}\right)$ and surface cooling heat fluxes $\left(Q_{o}=Q_{r}+Q_{r}+Q_{E}\right)$; (b) wind speed at $15 \mathrm{~m}$ height; (c) temperature difference $\Delta T=T_{0}-T_{8}$ in the near-surface layer of the ocean as measured by freerising proflier (asterisk) and simulated by transilient model (solid line); here $T_{0}$ and $T_{8}$ are the temperatures averaged over depth range $0-0.25 \mathrm{~m}$ and $8-8.25 \mathrm{~m}$. The measurements by free-rising profiler are the same as shown in Figs 6 and 7.

vertical profiles in Fig. $5 b$ is the strong variability of the depth of the diurnal thermocline. The contour plot of temperature (Fig. 12) calculated using measurements by bow sensors made on 26 April 1996, just before profiling shown in Fig. 5b, reveals wave-like disturbances of the diurnal thermocline of $\sim 200 \mathrm{~m}$ with amplitude $>1 \mathrm{~m}$. On the other hand, the profiles given in Fig. $5 \mathrm{c}$ show a much smaller variability. A contour plot of temperature calculated from bow record on 1 May 1996, just after the measurements given in Fig. 5c, is shown in Fig. 12. It is much "quieter" than the previous one, showing internal perturbations of 0.1 $0.2 \mathrm{~m}$.

Vertical profiles obtained by bow sensors during 26 April 1994 and 1 May 1994 are shown in Fig. 13. They are consistent with the results of measurements by free-rising profiler made during these two days (Fig. 5, $\mathrm{b}$ and $\mathrm{c}$ ).

Figure 14 shows another contour plot of temperature from bow sensor measurements made at the start of the evening deepening of the diurnal thermocline. There is a strong horizontal variability of diurnal heating in the near-surface layer. The perturbations look like internal waves developing at the diurnal thermocline. Internal waves developing on the shallow diurnal thermocline have been reported by Voropaev et al. (1981) and Imberger (1985). Soloviev and Lukas (1996) hypothesized that the internal waves in the diurnal thermocline may develop because of a resonant interaction (Phillips, 1969) between the 

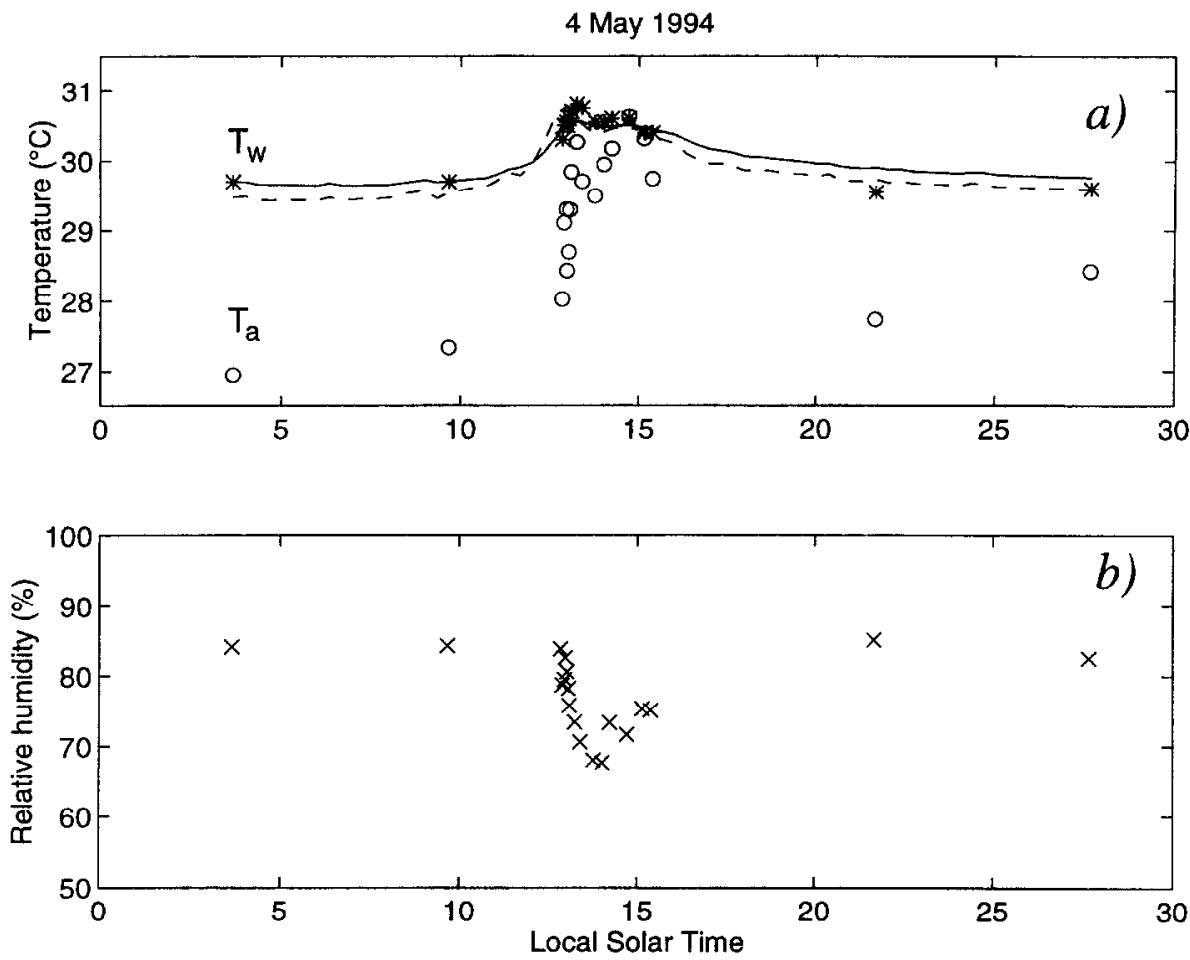

Fig. 10. (a) Air and water temperatures on 4 May 1996. Here, the asterisk is the bucket thermometer, open circle is the dry air temperature (corrected to $10 \mathrm{~m}$ height), solid line is the surface temperature ( $0-0.25 \mathrm{~m}$ average) calculated using the transilient model, and dashed line is the SST calculated using the transilient model and the cool skin model. (b) Relative humidity on 4 May 1996.

internal mode and a pair of surface waves with almost equal frequency and direction or because of the shear instability produced by the diurnal jet at the evening deepening.

\section{DISCUSSION AND CONCLUSIONS}

The amplitude of diurnal warming of the near-surface layer of the ocean dramatically increases at low wind speed because of damping turbulent mixing by positive buoyancy flux. The turbulent mixing in the near-surface layer of the ocean under light winds influences and is influenced by stratification due to diurnal heating. The diurnal cycle at low wind speed therefore can not be properly described in the framework of linear models implying constant coefficient of turbulent mixing in the surface layer of the ocean. The field data demonstrate that in calm weather and strong solar insolation the depth of the DML decreases to several centimeters and sometimes even vanishes. This results in an increased sensitivity of the diurnal cycle to the external forcing at low wind speed. The DML in calm weather may be maintained by the free convection driven by the ocean surface cooling or by salinity increase due to evaporation from the ocean surface. In calm weather, SST up to $33.25^{\circ} \mathrm{C}$ was observed; this was associated with a warming of more than $3^{\circ} \mathrm{C}$ in the top $1 \mathrm{~m}$ of the ocean. The heat content of this layer is small in comparison with that of the mixed layer of the ocean. However, it is not small in comparison with the heat content of the atmospheric 

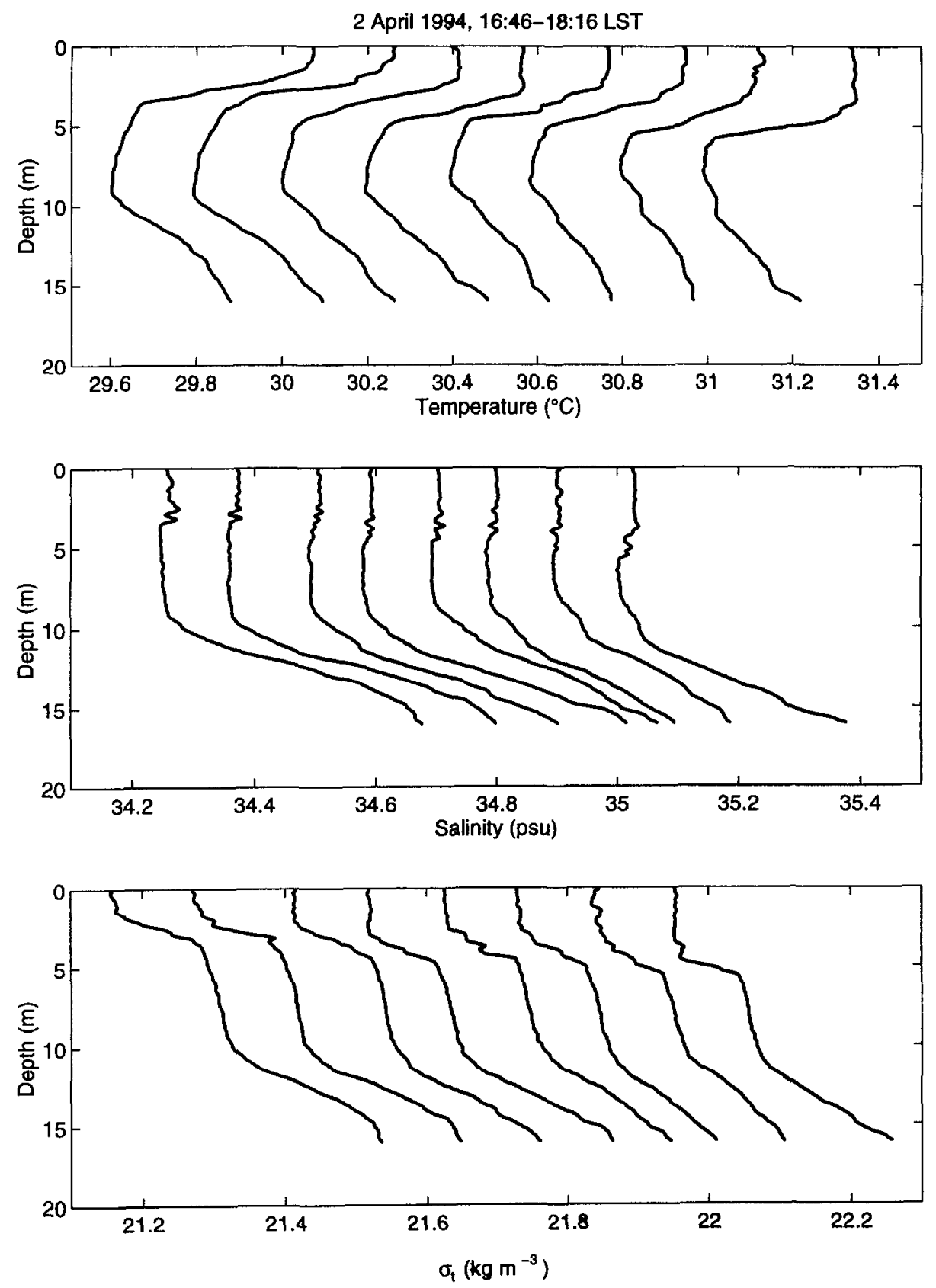

Fig. 11. Vertical temperature, salinity and density profiles obtained by free-rising profiler. Each temperature profile is shifted by $0.2^{\circ} \mathrm{C}$ for temperature, by $0.1 \mathrm{psu}$ for salinity and by $0.1 \mathrm{~kg} \mathrm{~m}^{-3}$ for density. 
26 April 1994, 15:16-15:22 LST

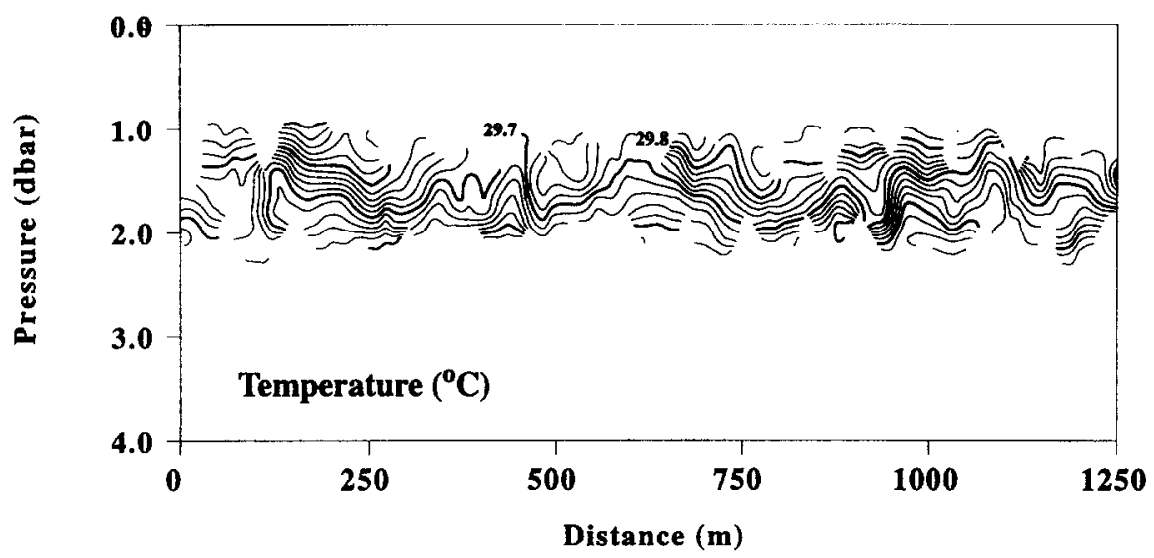

1 May 1994, 15:20-15:29 LST

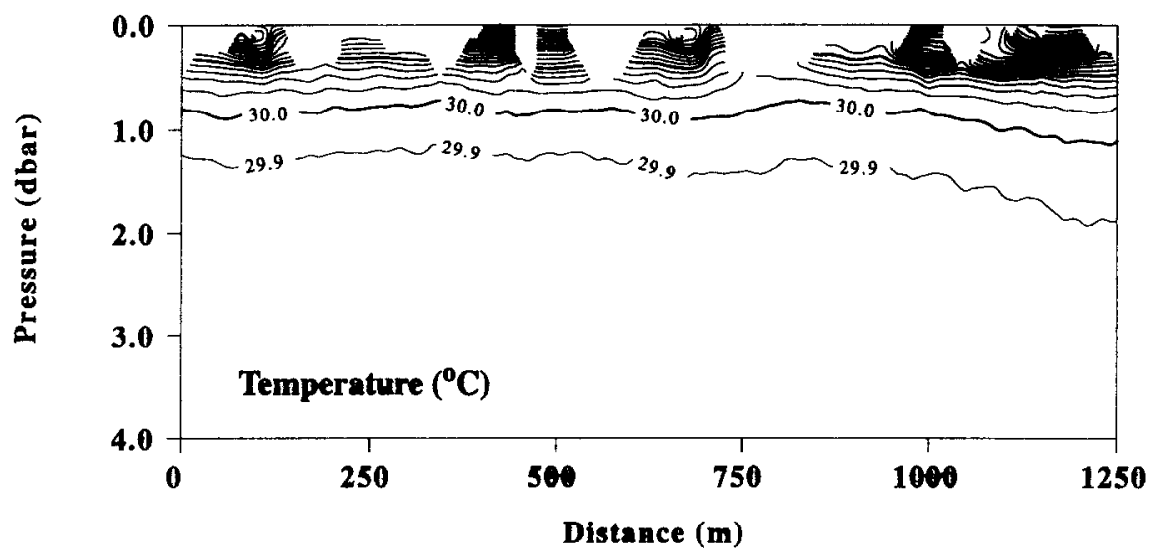

Fig. 12. Contour plots of temperature. Measurements by bow sensors on 26 April and on 1 May 1994.

boundary layer, because in heat capacity, $1 \mathrm{~m}$ water is equivalent to $1 \mathrm{~km}$ of air. In some sense, in calm weather the thermal behavior of the sea surface becomes analogous to that of the Earth surface. Rapid increase of SST due to diurnal heating of $1-3^{\circ} \mathrm{C}$ increases convection in the atmospheric boundary layer.

Salinity effects can be important during diurnal heating of the near-surface layer. Freshwater from precipitation influences the diurnal cycle by trapping heat near the surface. Another salinity effect is associated with evaporation from the ocean surface. Excess salinity is accumulated within the diurnal mixed layer, because turbulent exchange with the water below is damped by stable thermal stratification in the diurnal thermocline. Vertical salinity profiles show increases of salinity of about $0.01-0.02$ psu within the layer of diurnal heating. The corresponding density profiles are stable except for the diurnal mixed layer, where some inversions result from convective cooling and excess salinity due to evaporation. 

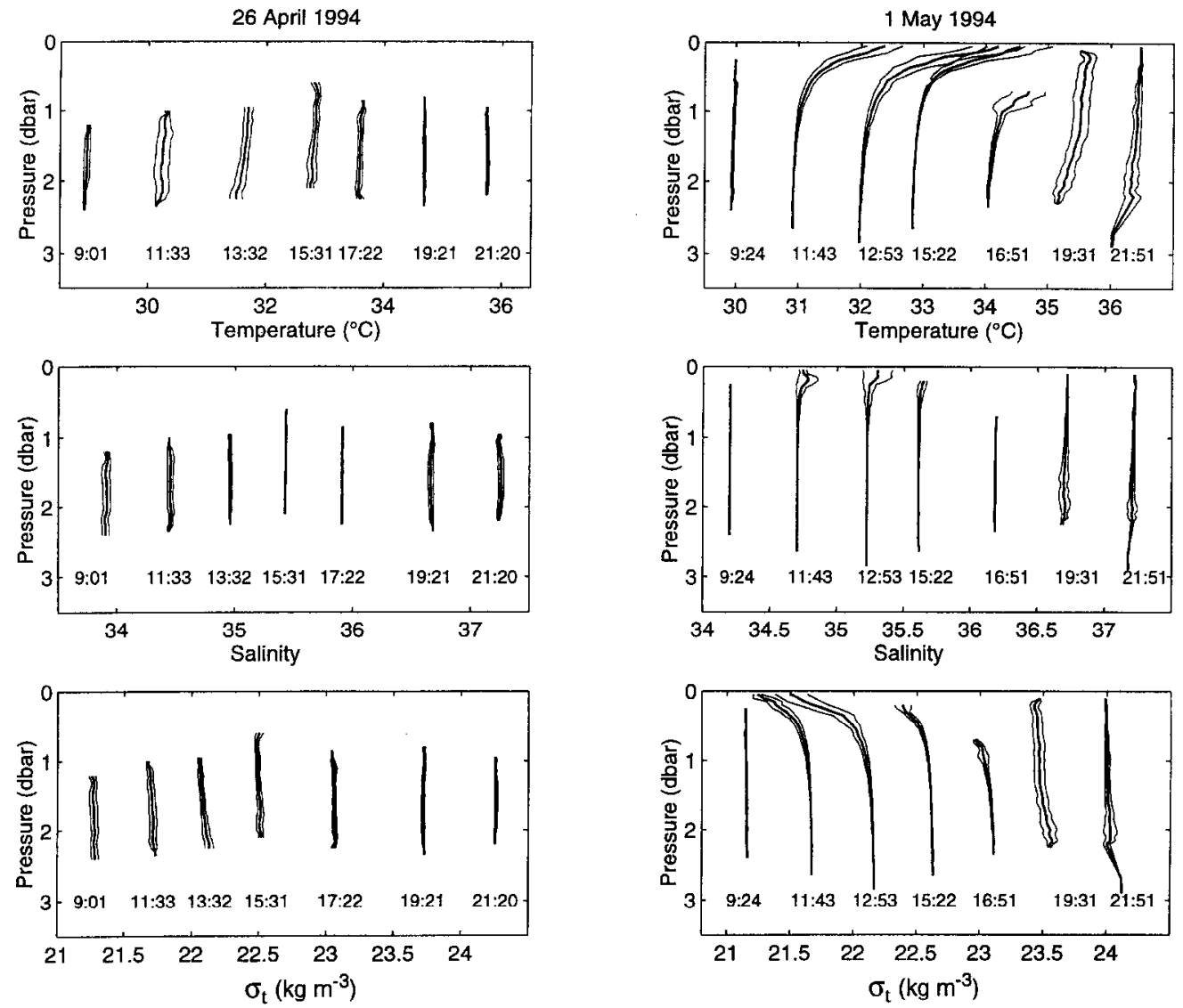

Fig. 13. Vertical profiles of temperature, salinity and density obtained by averaging the bow sensor data within $0.1 \mathrm{~m}$ depth range on $10 \mathrm{~min}$ segments. Each successive temperature, salinity and sigma-t profiles is shifted by $1.0^{\circ} \mathrm{C}, 0.5 \mathrm{psu}, 0.5 \mathrm{~kg} \mathrm{~m}^{-3}$. Under each profile the corresponding local solar time (LST) is given. The thin lines represent \pm one standard deviation.

A 1-D simulation of the data obtained during the special testing day, 4 May 1994, with the transilient model of Stull and Kraus (1987) gives good results. The experimental data during another day demonstrate, however, cases of a pronounced spatial variability of the diurnal thermocline. Causes of horizontal variability of diurnal heating include spatial variability of cloud and wind, as well as rain-caused relatively fresh lenses and the associated spatial variation of vertical salinity gradients near the surface. Horizontal variability of diurnal heating can also be due to internal processes in the near-surface diurnal thermocline on account of buoyancy adjustment and internal waves. Further progress in modeling the diurnal cycle seems therefore to be associated with development of 3-D models of the nearsurface layer of the ocean.

Acknowledgements-Michael Gregg (University of Washington) suggested the inclusion of such measurements in the near-surface layer of the ocean to the TOGA COARE planners. Bob Weisberg and Rick Cole (University of South Florida) and Linda Mangum (NOAA/PMEL) kindly included the measurements in the program of MW 9410 and MW9411 COARE cruises of the R.V. Moana Wave. Mark Baker (Johns Hopkins University) provided testing and post-calibration of the bow probes. Anatoli Arjannikov ("Granit", St Petersburg, Russia) and Jefrey Snyder 
(University of Hawaii) provided technical support for the measurements and pre-cruise calibration of the instrumentation. Sharon DeCarlo (University of Hawaii) and Dmitry Khlebnikov (P. P. Shirshov Institute of Oceanology, Russia) wrote software for recording and preliminary processing of the data. The assistance of the crew of the R.V. Moana Wave was crucial for success of the program. The study has been supported by the U.S. National Science Foundation (Grant OCE-9216891), the Office of Naval Research (Grant N0014-961-0832) and the Russian Academy of Sciences.

\section{REFERENCES}

Anderson, S. R., Weller, R. A. and Lukas, R. (1996) Surface buoyancy forcing and the mixed layer in the warm pool: observations and 1-D model results. Journal of Climate, 9, 3056-3085.

Bruce, J. C. and Firing, E. (1974) Temperature measurements in the upper $10 \mathrm{~m}$ with modified expendable bathythermograph probes. Journal of Geophysical Research, 79, 4110-4111.

Chen, S. S., Houze, R. A. Jr, Mapes, B. E. (1996) Multiscale variability of deep convection in relation to largescale circulation in TOGA COARE. Journal of Atmospheric Sciences, 53, 1380-1409.

Fedorov, K. N. and Ginzburg, A. I. (1988) Physics of near-surface layer of the ocean, Hydrometeoizdat, Leningrad, 303 pp. (in Russian).

Flament, P., Firing, J., Sawyer, M. and Trefois, C. (1994) Amplitude and horizontal structure of a Large Diurnal Sea Surface Warming Event during the Coastal Ocean Dynamics Experiment. Journal of Physical Oceanography, 24, $124-139$.

Gautier, C. (1978) Some evidence of cool surface water pools associated with mesoscale downdrafts during GATE. Journal of Physical Oceanography, 8, 162-166.

Greenhut, G. K. (1978) Correlations between rainfall and sea surface temperature during GATE. Journal of Physical Oceanography, 8, 1135-1138.

Hoeber, H. (1969) Wind-, Temperatur- und Feuchteprofile in der wassernahen Luftschicht uber dem aquatorialen Atlantik. Sonderdruck aus Meteor. Forschungsergebnisse Reihe B, Heft 3. Berlin, Stuttart: Geburder Bomtrager, p. 1.

Imberger, J. (1985) The diurnal mixed layer. Limnology and Oceanography, 30(4), 737-770.

Khlebnikov, D. V. and Soliviev, A. V. (1990) The transilient model of the near-surface layer of the ocean. Fine structure and synoptic variability of the sea and ocean. Tallinn, pp. 154-155 (in Russian).

Kraus, E. B. and Businger, J. A. (1994) Atmosphere-Ocean Interaction. Second edition. Oxford University Press, New York, 362 pp.

Kraus, E. B. and Rooth, C. G. H. (1961) Temperature and steady state vertical heat flux in the ocean surface layers. Tellus, 13, 231-238.

Kudryavtsev, V. N. and Soloviev, A. V. (1990) Slippery near-surface layer of the ocean arising due to daytime solar heating. Journal of Physical Oceanography, 20, 617-628.

Lukas, R. (1990a) Freshwater input to the western equatorial Pacific Ocean and air-sea interaction. In: Proceedings of the Symposium on Western Tropical Pacific Air-Sea Interactions, China Ocean Press, Beijing, 15-17 November 1988, pp. 305-327.

Lukas, R. (1990b) The role of salinity in the dynamics and thermodynamics of the western Pacific warm pool. In International TOGA Scientific Conf. Proc., WCRP-43, WMO/TD, Vol. 379, pp. 73-81

Lukas, R. (1991) The diurnal cycle of sea surface temperature in the western equatorial Pacific. TOGA Notes, January 1991, No. 2, pp. 1-5.

Lukas, R. and Lindstrom, E. (1991) The mixed layer of the western equatorial Pacific Ocean. Journal of Geophysical Research, 96(suppl.), 3343-3357.

Oppenheim, A. V. and Schafer, R. W. (1975) Digital Signal Processing, Prentice-Hall, Englewood Cliffs, NI.

Payne, R. E. (1972) Albedo of the sea surface. Journal of the Atmospheric Sciences, 29, 959-970.

Phillips, O. M. (1969) The dynamics of the upper ocean. Cambridge University Press, Cambridge, U.K.

Simpson, J. J. and Paulson, C. A. (1979) Mid-ocean observations of atmospheric radiation. Quarterly Journal of the Royal Meteorological Society, 105, 487-502.

Soloviev, A. V. (1979) Thin thermal structure of the ocean surface layer in the POLYMODE-77 region, Izvestia. Atmospheric and Oceanic Physics, 15, 750-754.

Soloviev, A. V. and Lukas R. (1996) Observation of spatial variability of diurnal thermocline and rain-formed halocline in the western Pacific warm pool. Journal of Physical Oceanography, 26, 2529-2538.

Soloviev, A. V. and Schluessel, P. (1996) Evolution of cool skin and direct air-sea gas transfer coefficient during daytime. Boundary Layer Meteorology, 77, 45-68. 
Soloviev, A. V. and Vershinaky, N. V. (1982) The vertical structure of the thin surface layer of the ocean under conditions of low wind speed. Deep-Sea Research, 29, 1437-1449.

Soloviev, A. V., Vershinsky, N. V. and Bezverkhnii, V. A. (1988) Small-scale turbulence measurements in the thin surface layer of the ocean. Deep-Sea Research, 35, 1859-1874.

Soloviev, A. V., Lukas, R., DeCarlo, S., Snyder, J., Arjannikov, A., Baker, M. and Khlebnikov, D. (1995) Small-scale measurements near the ocean-air interface during TOGA-COARE. Data Report, SOEST-95-05, University of Hawaii, Honolulu, HI, $257 \mathrm{pp}$.

Stramma, L., Cornillon, P., Weller, R. W., Price, J. F. and Briscoe, M. G. (1986) Large diurnal sea surface temperature variability. Satellite and in-situ measurements. Journal of Physical Oceanography, 16, 827-837.

Stull, R. B. and Kraus, E. B. (1987) The transilient model of the upper ocean. Journal of Geophysical Research, 92, 10745-10755.

Taft, B. A. and McPhaden, M. J. (1990) Diurnal cycle of sea surface temperature in the western tropical Pacific. In: Proceedings of the Symposium on Western Tropical Pacific Air-Sea Interaction, China Ocean Press, Beijing, 15-17 November 1988, pp. 343-352.

Turner, J. S. (1973) Buoyancy effects in fluids. Cambridge University Press, Cambridge, U.K.

Voropaev, S. I., Gavrilin, B. L. and Zatsepin, A. G. (1981) On the structure of the surface layer of the ocean. Izv Akad. Nauk SSSR, . Atmospheric and Oceanic Physics, 17, 378-382.

Webster, P. J. and Lukas, R. (1992) TOGA COARE: The Coupled Ocean-Atmosphere Response Experiment. Bulletin of the American Meteorological Society, 73(9), 1377-1416.

Webster, P. J., Clayson, C. A. and Curry, I. A. (1996) Clouds, radiation, and the diurnal cycle of the sea surface temperature in the tropical western Pacific. Journal of Climate, 9, 1712-1730.

\section{APPENDIX}

\section{TRANSILIENT MODEL OF DIURNAL CYCLE}

The transilient model deals with the parameterization of turbulent transports by a spectrum of eddies that transport fluid properties over a range of distances. We used the transilient model as it was described by Stull and Kraus (1987) with the scaling velocity, $U_{0}=u_{*}$, and the vertical length scaling, $L_{0}=\kappa z$, where $u_{*}$ is the frictional velocity in water, $z$ is the depth, and $\kappa=0.4$ is the von Karman constant. For the unstably stratified near-surface layer (nighttime) we uscd the scaling: $U_{0}=w_{*}, L_{0}=L_{C}$, wherc $w_{*}=\left(L_{C} B_{0}\right)^{1 / 3}, L_{C}$ is the depth of the unstably stratified near-surface layer, and $B_{0}$ is the surface buoyancy flux. Khlebnikov and Soloviev (1990) added a salinity budget equation to the original model of Stull and Kraus (1987). The absorption of solar radiation with depth was parameterized by a 9 exponential dependence in accordance with Soloviev and Schluessel (1996). To calculate the albedo for the short-wave radiation forcing, we used the Fortran code written by Peter A. Coppin (CSIRO Centre for Environmental Mechanics, Australia), employing the Payne (1972) model.

The transilient model was forced by the wind stress and sensible and latent heat fluxes, calculated using the TOGA COARE bulk-flux algorithm (version 2.5a). The net longwave radiation flux was calculated using the parameterization of Simpson and Paulson (1979).

For simulation of the diurnal cycle on 4 May 1994 (Fig. 9 and 10), we employed the transilient model with the 80 evenly spaced grid points within the top $20 \mathrm{~m}$ of the ocean. The vertical resolution and the time step were $0.25 \mathrm{~m}$ and $15 \mathrm{~s}$. The vertical profiles of temperature and salinity were initialized to be constant in the upper $20 \mathrm{~m}$ of the ocean, while the velocity profile was initialized by a $0.0004 \mathrm{~s}^{-1}$ shear to avoid infinite values of the Richardson number at the first step of the simulation. 